\title{
The Relationship between Corporate Social Responsibility and Financial Performance of Iraqi Corporations: A Literature Review
}

\author{
Anmar Adnan Khudhair, Norlia Mat Norwani, Azam Abdel Hakeem Khalid Ahmed \\ University Pendidikan Sultan Idris (UPSI), Perak Darul Ridzuan, Malaysia \\ Talal Mohammed Aljajawy \\ University of Karbala, Kerbala, Iraq
}

\begin{abstract}
This paper aims to explore past researches that examine the relationship between corporate social responsibility (CSR) and financial performance. The researcher intends to conduct researches that examine the relationship between CSR and financial performance in Iraq corporations. This paper highlights review of literatures from various countries that examine relationships between CSR with financial performance. This paper is based on secondary sources which are accumulated from many researches in Malaysia, Australia, UK, Indonesia, Sri Lanka, Nigerian, and Jordan. The study uses information generated from literature reviewed from different researchers relating to the topic. This method was applied by collecting information from journals and online sources relating to the issue under consideration. Regression analysis documents significant evidence to support a positive relationship between CSR and financial performance. Evidence suggests that CSR leads to good financial performance in Iraq corporations. Findings based on the review revealed that researchers also showed that there was a significant positive relationship between CSR practice and financial performance in Iraq corporations. This study focuses on disclosures made in the corporate annual reports. This is because the annual report is the common document produced by companies on a regular basis and is widely used in prior studies related to CSR. The study provides some important insights for our understanding of CSR in developing economies and its effects on financial performance in the context of Iraq companies.
\end{abstract}

Keywords: corporate social responsibility, financial performance, Iraq, stakeholder theory

\section{Introduction}

Corporate social responsibility is an activity done by a company as a solution for a company to consider when it comes to improvising their reputation (Burianová \& Paulik, 2014; Niresh \& Silva, 2018). According to

\footnotetext{
Anmar Adnan Khudhair, Department of Accounting, Faculty of Management and Economics, University Pendidikan Sultan Idris (UPSI), Perak Darul Ridzuan, Malaysia.

Norlia Mat Norwani, Profesor Madya Dr. Department of Accounting, Faculty of Management and Economics, University Pendidikan Sultan Idris (UPSI), Perak Darul Ridzuan, Malaysia.

Azam Abdel Hakeem Khalid Ahmed, Dr, Department of Accounting, Faculty of Management and Economics, University Pendidikan Sultan Idris (UPSI), Perak Darul Ridzuan, Malaysia.

Talal Mohammed Aljajawy, Profesor, Department of Accounting, Faculty of Management and Economics, University of Karbala, Kerbala, Iraq.
} 
Njeri (2013), investment of the shareholder will be rewarded due to good financial performance. This encourages further investments to be made and encourages economic growth. However, poor performance may cause failure and severe crisis which may give negative impact on the economic growth. The efficiency of an institution and its ability to attain the revenues and profits are measured based on the firm's performance (Ongore \& Kusa, 2013).

In general, CSR has become a global issue to all the organizations around the world. It is a strategy for a company to voluntarily integrate the social and environmental matters with their business operation and enhance stakeholders' interaction (McGill, Enquist, Weiher, \& Westoby, 2016). Meanwhile, Turker (2009) explained that CSR is a relationship between business, environment, and society. CSR covers wide range of issues, such as poverty, social equity, human rights, corruptions, and community relationship. In the economic aspects, CSR covers the employment issues, growth rate, and even gross domestic product (GDP) (Cheng, Ioannou, \& Serafeim; Vigneau, Humphreys, \& Moon, 2015).

A firm's financial performance can be determined from various perspectives as there have been varieties of definition related to firm's performance. According to Harrison and Wicks (2013), financial performance is the total value that had been created by the firm based on their activities. It is the sum of the efficacy created for each of a firm's authentic stakeholders. From the accounting point of view, the theory and practice have developed a range of possible approaches to the measurement of financial performance (Strouhal, 2015). The accounting researchers used profitability as a performance indicator to assess the achievements of the company (Nuryaman, 2013; Setiawan \& Dermawan, 2011). Financial performance can also be defined as a subjective assessment on how well a firm can utilize the asset based on its primary business to generate the revenues. Additionally, it is also used as a general measure of the firm's overall financial status through a certain period of time to compare the firms across the same industry or between industries or sectors collectively.

Framework between CSR and financial performance has been set in order for the company to claim their resources (Santoso \& Feliana, 2014). Furthermore, with the existence of framework, it has implicitly encouraged the company to practice appropriate behaviour, such as their consideration towards the environment and awareness on the labour's relations (Rodriquez-Fernandez, 2016). However, if the companies do not comply with the social responsibility, it may lead to the resultant costs which can lead to financial burden, such as reducing the profits, and even worse, lack of social awareness upon their entity. In contrast, if the companies fulfil the social responsibility policies, they will earn more profits and their social responsible investment will help to increase their business incentives. Overall, it can be concluded that investing in CSR can lead to various positive outcomes, such as strengthening the financial aspects of the company, reduces fire risk, and can even lead to a better long-run growth aspects (Lin, Ho, Ng, \& Lee, 2017). .

\section{Litterateur Review}

This work is placed within the theory of stakeholders, which is widely employed as a framework to understand CSR, CSR disclosure, and CSR reporting and its relationship with financial performance (Odriozola \& Baraibar-Diez, 2017). According to Jeon, Lee, Yang and Kim (2018), the outcome of the previous studies has proven that corporate transparency can enhance the firm's profitability and sustainability.

\section{Theoretical Framework}

The discussion so far has described the emergence of CSR as a framework for the role of business in 
society, setting standards of behavior to which companies must subscribe to impact society and environment in a positive and a productive manner. The following represents the major theory that supports the practice of CSR.

\section{Stakeholder Theory}

In general, stakeholder theory is a type of theory that had been adopted in CSR and sustainability studies and is claimed to be a crucial element in CSR operation (Bondy, Moon, \& Matten, 2012; Ado, 2016). They comprise of individuals and constituencies that contribute voluntarily and involuntarily to the firms' wealth and activities that leads them as the potential beneficiaries. Besides that, other definition elaborated that stakeholders are identifiable group or individuals who can lead to positive achievement to the organization's objectives. Specifically, stakeholders are shareholders, employees, suppliers, consumers, government, media, creditors, interest groups, and general public. This theory suggested that superior firm performance can be created if the corporations meet the expectations of various stakeholders (Arshad, S. Othman, \& R. Othman, 2012). Generally, stakeholder theory is prioritizing the relationship between an organization and its stakeholders. This is because the central idea of the theory is to attain success which depends on the capability of the company to sustain their relationship with the stakeholder groups, such as employees, customers, and even general public (Niresh \& Silva, 2018).

\section{The Relationship Between CSR and Financial Performance}

This research focuses on the integration between CSR according to the indicators of Global Reporting Initiatives and financial performance of Iraqi corporates the scope limited to listed corporate in the Stock Exchange of Iraqi. Those companies were selected as the population of the study because they are expected to increase stakeholder engagement and CSR disclosure after substantial encouragement from the regulators. Data on stakeholder salience and stakeholder engagement were confined to the perception of each of six stakeholder groups collected from questionnaires given to companies' executives. Data on CSR disclosure were confined to CSR information regarding the issues related to the perspective of each of the six stakeholder groups disclosed in corporate annual reports (Pankeowta, 2012).

Recently, the United State companies again were used as samples in research about the impact of CSR on financial performance conducted by Grigoris (2016). The result also supports findings of previous researchers that the higher CSR disclosure score is, the greater financial performance company can has. Positive relationship between CSR and financial performance also was witnessed in study conducted by Adeneye and Ahmed (2015) who used bivariate and multivariate analysis to analyses data of 500 firms in the United Kingdom. As a result of that, authors recommended that UK firms should make more efforts to carry out their corporate social responsibilities if they want to increase their financial performance.

Most CSR studies are based on the western perspectives, practices, and values which are highly related to specific interests and the needs of certain groups and situations (Fasanya \& Onakoya, 2013; Giannarakis, Konteos, Zafeiriou, \& Partalidou, 2016). Based on prior studies, many have reported that there have been a positive relationship and there had been no single theoretical foundation that shows clear prediction for CSR and financial performance relationship. Thus, based on the theoretical and empirical evidence of the past studies, this study aims to predict similar outcome that there will be a directional positive relationship between CSR and the firm’s financial performance (Saleh, Zulkifli, \& Muhamad, 2011; Dhaliwal et al., 2014; Eccles, 
Ioannou, \& Serafeim, 2012; Khaveh, Nikhasemi, Haque, \& Yousefi, 2012).

Meanwhile, corporate responsibility reporting refers as a communication tool used by the companies to portray their performance. It is also a tool to allow the managers to evaluate continuous improvement in non-financial areas based on the data provided by the companies to the stakeholders. The first step to improve the performance is by changing the actual practices of companies in their daily activities and making them more responsive to global challenges and community needs. Transparency is, therefore, must be a concept that related to reporting in general, particularly reporting on sustainability or corporate responsibility (CSR). Companies have been consistently emphasizing the need for transparency due to the growing pressure from the regulators, customers, and investors in order to be transparent to the economic, social, and environmental dimensions. Thus, it is necessary to promote and report corporate responsibility as it is also a mean to improve transparency (Lydenberg, Rogers, \& Wood, 2010).

The prior researches provide no clear and precise relationship between CSR and financial performance. The results are mixed and often contradictory. Now, we organize the literature review into different parts, exhibiting positive, negative, not significant, or mixed relationship to bring more clarity and make it easier to comprehend the nature of association between CSR and corporate financial performance.

\section{Research Method}

The study used information generated from literature reviewed by different researchers relating to the topic. This method was applied by collecting information from journals and online sources relating to the issue under consideration.

\section{Conclusions}

The objective of this paper is to analyze the relationship between corporate social responsibility (CSR) and corporate financial performance (CFP). This study concludes from above empirical literature evidences that corporate social responsibility (CSR) is highly linked with corporate financial performance (CFP). The number of companies who issue CSR reports has significantly increased during the last decade. Various researches have been conducted over the last decade for examining the linkage between sustainability reporting and corporate financial performance. There also exists a strong theoretical framework in support of CSR reporting, encompassing Stakeholder.

Particularly, 20 studies have been analyzed in this regard. The results are mixed and range from positive, to negative, to the statistically insignificant relationship, depending upon the choice of measure of CSR reporting (maybe disclosure index scores, independent CSR ratings, dummy variables indicating issue of GRI Report, or membership of popular sustainability indices); measure of financial performance (maybe cost of capital, accounting-based measures, market-based measures, or mixture of these measures); and sample selection (large or small sample size; from developed or developing countries). Out of 20 studies, 11 exhibits positive relationship, three show a short-term negative relationship, four show no significant relationship, and two studies (most of which used disaggregated approach) provide mixed results. They show that various indicators of sustainability (environment, economic, and social) have varying impacts on different measures of financial performance. Thus, majority of studies suggest that CSR reporting enhance corporate reputation and financial performance as it results in various synergies and benefits accruing to the reporting firm. 


\section{Reference}

Adeneye, Y. B., \& Ahmed, M. (2015). Corporate social responsibility and company performance. Journal of Business Studies Quarterly, 7(1), 151.

Ado, R. (2016). Accounting, accountability, and governance in upstream petroleum contracts: The case of local content sustainability in the Nigerian oil and gas sector (Ph.D. thesis, Gordon University).

Arshad, R., Othman, S., \& Othman, R. (2012). Islamic corporate social responsibility, corporate reputation, and performance. World Academy of Science, Engineering and Technology, 64(4), 1070-1074.

Bondy, K., Moon, J., \& Matten, D. (2012). An institution of corporate social responsibility (CSR) in multi-national corporations (MNCs): Form and implications. Journal of Business Ethics, 111(2), 281-299.

Burianová, L., \& Paulík, J. (2014). Corporate social responsibility in commercial banking: A case study from the Czech Republic. Journal of Competitiveness, 6(1).

Cheng, B., Ioannou, I., \& Serafeim, G. (2014). Corporate social responsibility and access to finance. Strategic Management Journal, 35(1), 1-23.

Dhaliwal, D. S., Li, O. Z., Tsang, A., \& Yang, Y. G. (2014). Corporate social responsibility disclosure and the cost of equity capital: the roles of stakeholder orientation and financial transparency. Journal of Accounting and Public Policy, DOI: 10.1016/j.jaccpubpol.2014.04.006.

Eccles, R. G., Ioannou, I., \& Serafeim, G. (2012). The impact of a corporate culture of sustainability on corporate behavior and performance. Retrieved from https://www.eticanews.it/wp-content/uploads/2012/10/Studio-Harvard.pdf

Fasanya, I. O., \& Onakoya, A. B. (2013). Does corporate social responsibility improve financial performance of Nigerian firms? Empirical evidence from triangulation analysis. Acta Universitatis Danubius, 9(3), 22-36.

Giannarakis, G., Konteos, G., Zafeiriou, E., \& Partalidou, X. (2016). The impact of corporate social responsibility on financial performance. Investment Management and Financial Innovations (Open-Access), 13(3-1), 1-3.

Grigoris, G. (2016). The challenges of corporate social responsibility assessment methodologies. International Journal of Economics \& Business Administration (IJEBA), 4(1), 39-55.

Harrison, J. S., \& Wicks, A. C. (2013). Stakeholder theory, value, and firm performance. Business Ethics Quarterly, 23(1), 97-124.

Herdiyana, H., \& Setiawan, N. (2018). Financial performance in value in the automotive sector and components go public in Indonesia. Jurnal Ilmiah Manajemen Fakultas Ekonomi (JIMFE), 2(1), 30-40.

Jeon, N. J., Na, H., Jung, E. H., Yang, T. Y., Lee, Y. G., Kim, G., \& Seo, J. (2018). A fluorene-terminated hole-transporting material for highly efficient and stable perovskite solar cells. Nature Energy, 3(8), 682.

Khaveh, A., Nikhasemi, S. R., Haque, A., \& Yousefi, A. (2012). Voluntary sustainability disclosure, revenue, and shareholders wealth: A perspective from Singaporean companies. Business Management Dynamics, 1(9), 6-12.

Kim, C. H., Amaeshi, K., Harris, S., \& Suh, C. J. (2013). CSR and the national institutional context: The case of South Korea. Journal of Business Research, 66(12), 2581-2591.

Lin, W. L., Ho, J. A., Ng, S. I., \& Lee, C. (2017). Impact of positive and negative corporate social responsibility on corporate financial performance and idiosyncratic risk. Retrieved from http://www.econ.upm.edu.my/content/impact_of_positive_and_negative_corporate_social_responsibility_on_corporate_fina ncial_performance_and_idiosyncratic_risk-35633

Lydenberg, S. D., Rogers, J., \& Wood, D. (2010). From transparency to performance: Industry-based sustainability reporting on key issues. Cambridge, MA: Hauser Center for Nonprofit Organizations.

McGill, B. J., Enquist, B. J., Weiher, E., \& Westoby, M. (2016). Rebuilding community ecology from functional traits. Trends in Ecology \& Evolution, 21(4), 178-185.

Nguyen, N. (2018). The effect of corporate social responsibility disclosure on financial performance: Evidence from credit institutions in Vietnam. Asian Social Science, 14(4), 109.

Niresh, J. A., \& Silva, W. H. E. (2018). The Nexus between corporate social responsibility disclosure and financial performance: Evidence from the listed banks, finance and insurance companies in Sri Lanka. Accounting and Finance Research, 7(2), 65.

Njeri, N. J. (2013). The relationship between transparency, disclosure and financial performance of insurance companies in Kenya. $\quad$ Retrieved from http://erepository.uonbi.ac.ke/bitstream/handle/11295/62220/Ndungu_The\%20relationship\%20between\%20transparency,\%2 0disclosure\%20and\%20financial\%20performance.pdf?sequence $=3$ 
Nuryaman, A. R. (2013). The effect of corporate social responsibility activities on profitability and stock prices. Journal of Global Management, 6(1), 113-124.

Odriozola, M. D., \& Baraibar-Diez, E. (2017). Is corporate reputation associated with quality of CSR reporting? Evidence from Spain. Corporate Social Responsibility and Environmental Management, 24(2), 121-132.

Ongore, V. O., \& Kusa, G. B. (2013). Determinants of financial performance of commercial banks in Kenya. International Journal of Economics and Financial Issues, 3(1), 237.

Pankeowta, L. (2012). The influence of stakeholder salience and engagement on corporate social responsibility (CSR) Disclosure of companies listed on the Stock Exchange of Thailand (Doctoral dissertation, Universiti Utara Malaysia).

Rodriguez-Fernandez, M. (2016). Social responsibility and financial performance: The role of good corporate governance. BRQ Business Research Quarterly, 19(2), 137-151.

Saleh, M., Zulkifli, N., \& Muhamad, R. (2011). Looking for evidence of the relationship between corporate social responsibility and corporate financial performance in an emerging market. Asia-Pacific Journal of Business Administration, 3(2), 165-190.

Santoso, A. H., \& Feliana, Y. K. (2014). The association between corporate social responsibility and corporate financial performance. Social and Environmental Accounting, 8(2), 82-103.

Setiawan, M. (2011). Darmawan. (2011). The relationship between corporate social responsibility and firm financial performance: evidence from the firms listed in LQ45 of the Indonesian Stock Exchange Market. European Journal of Social Sciences, 23(2), 288-293.

Strouhal, J., Gurvits, N., Nikitina-Kalamäe, M., \& Startseva, E. (2015). Finding the link between CSR reporting and corporate financial performance: Evidence on Czech and Estonian listed companies. Central European Business Review, 4(3), 48.

Turker, D. (2009). Measuring corporate social responsibility: A scale development study. Journal of Business Ethics, 85(4), 411-427.

Vigneau, L., Humphreys, M., \& Moon, J. (2015). How do firms comply with international sustainability standards? Processes and consequences of adopting the global reporting initiative. Journal of Business Ethics, 131(2), 469-486.

Table 1

Positive and Negative Relationship Between CSR and Financial Performance

\begin{tabular}{lll}
\hline No. & Studies & Result \\
\hline 1. & Greenwald (2010) & Positive \\
2. & Saleh, Zulkifli, \& Muhammad (2011) & Positive \\
3. & Dhaliwal et al. (2012) & Positive \\
4. & Eccles et al. (2012) & Positive \\
5. & Khaveh et al. (2012) & Positive \\
6. & Detre and Gunderson (2011) & Negative \\
7. & Khaveh et al. (2012) & Positive \\
8. & Mohd Taib and Ameer (2012)-UK and US & Mixed \\
9. & Flammer (2015), & Positive \\
10. & Beredugo (2012) & Positive \\
11. & Norhasimah (2015) & Positive \\
12. & Akinlo \& Iredele (2014) & Positive \\
13. & Nguyen, N. (2018) & Negative \\
14. & Adams et al. (2012)-US & No significant \\
15. & Lopez et al. (2007) & Negative \\
16. & Bayoud et al. (2012)-Libya & Mixed \\
17. & Humphrey et al. (2012)-UK & No significant \\
18. & Niresh and Silva (2018) & Positive \\
19. & Maria-Gaia Soana (2011) & No significant \\
20. & Rahmawati and Putrid Septia Danita (2011) & No significant \\
\hline
\end{tabular}

